use this opportunity to thank the entire staff. And I recognize the five years of Julie Virgo's exceptional contributions and, on behalf of the membership, offer her our deep appreciation for her helping ACRL to be a major force in our profession.

David C. Weber President, ACRL

\title{
A Conversation with Carla Stoffle
}

Editor's Note: In June I had the opportunity to speak with Carla Stoffle, vice-president/ president-elect of ACRL, about the immediate future of ACRL and its activities.

Stoffle has been assistant chancellor for educational services at the University of Wisconsin-Parkside since 1978. She begins her term of office as 44th president of $A C R L$ at the end of the ALA annual conference in Philadelphia.

Ed.: What type of

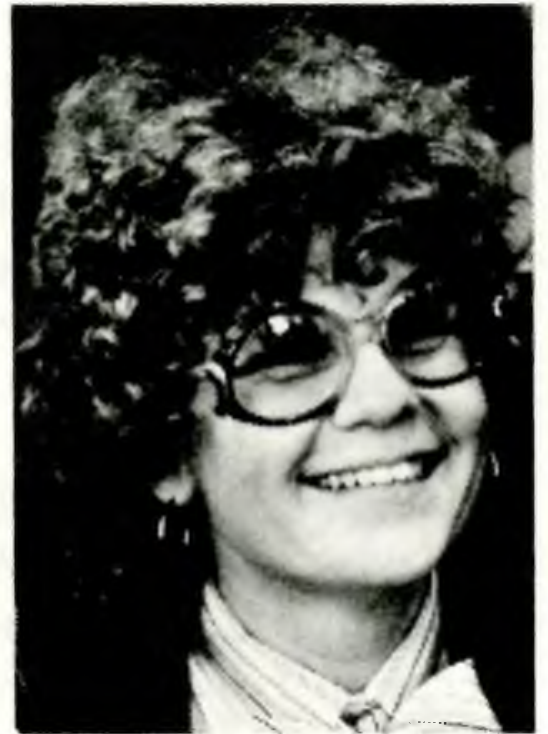

Carla Stoffle UW-Parkside areas of librarianship will you be emphasizing during your term as ACRL president?

Stoffle: I will be trying to encourage a response to the ACRL Activity Model for 1990. Much time and many resources were put into its development, and I hope that ACRL members will examine the proposal's recommendations closely. In order to ensure that ACRL remains a strong, viable organization in the future, the model's priorities will have to be continually examined. I would like to see the ACRL Planning Committee constantly identifying priorities and the ACRL Board using the Activity Model as a framework to judge the Association's activities.

Next year my presidential theme will be "Building Bridges." I would like to build bridges to other divisions and offices in ALA and improve the lines of communication with library schools. The Bibliographic Instruction Liaison Project will allow ACRL to build bridges with other professional associations, not only in terms of BI, but for the benefit of academic librarianship as a whole. I am also looking into a task force or discussion group on the role of academic libraries in higher education agencies and organizations.

Ed.: You have been a college administrator for four years now. From your perspective, what must academic librarians do to show administrators how vital their libraries are to higher education?

Stoffle: They need to take well-planned risks. I prefer an environment where people take the initiative and tell me as an administrator what direction they should be going in and how they should fit into the long-range goals of the institution. I think that librarians do not adequately communicate their victories and philosophies of librarianship to the senior administration. Nor do we communicate the potential the library has to assist many institutional programs. We should stimulate the faculty to examine their curriculum and teaching methods periodically simply by exposing them to library materials and services. Academic librarians can bring many research tools to their attention or enable them to shift their research focus by being involved in their subject areas and finding new information for them.

Very few libraries will be able to buy everything that someone on campus might want them to have. Collection development has become a major problem in the $80 \mathrm{~s}$-libraries not only must investigate resource-sharing, but they also need to offer alternative services to their parent institution to be active and effective on campus.

Ed.: Your publishing record and your association with the Bibliographic Instruction Section show you to be a most active proponent of BI. How does bibliographic instruction fit into ACRL's future?

Stoffle: Bibliographic instruction librarians are concerned about the educational mission of the academic library in the broad sense as well as in specific programs. BIS members may become more involved in ACRL or ALA-wide programs. ACRL has played a critical role in the growth of instruction programs and in the acceptance of instruction by the profession in the last 25 years. The Association has and will continue to recognize the importance of $\mathrm{BI}$, provide a framework for people with ideas who need to share those ideas with others, and provide training and legitimacy for user instruction professionals. 
Ed.: How can an ALA divisional president ensure that the division's concerns are understood within ALA Council?

Stoffle: If we continue to approach ALA as individual divisions clamoring for our own special self-interests, we will not necessarily improve our own programs or contribute to a strengthened ALA. One of the issues I am very concerned about is the divisions' relationship to ALA. If ALA is not strong the divisions will also fare poorly. We need to take ALA-wide concerns into account as well as our own local needs.

I have arranged a meeting at annual conference in Philadelphia with all the other divisional vicepresident/president-elects. We will try to understand and coordinate each other's concerns. I was surprised to find out that I did not know most of the other divisional vice-presidents-some of them knew more of us than I did, but no one knew the majority of their counterparts. Nor did we know what we each were trying to achieve in our upcoming terms. This meeting will improve the communication lines.

Ed.: Have you learned a lot in your year as vice-president that will help you to weather the storms you may face next year as president of ACRL?

Stoffle: I was overwhelmed when I discovered all the things that the president and vice-president need to know and do. I have had good teachers in Penny Abell and David Weber, but it will be a much bigger job than I had thought. Perhaps

\section{BUDINGTON NAMED LIBRARIAN OF THE YEAR}

William Stone Budington, director of the John Crerar Library, has been awarded the ACRL Academic/Research Librarian of the Year Award for 1982. ACRL and the Baker \& Taylor Company presented the award to Budington on July 12 at the ACRL reception during ALA's Annual Conference in Philadelphia.

The award cites Budington for his work in serving as president of the Special Libraries Association (1964-65) and the Association of Research Libraries

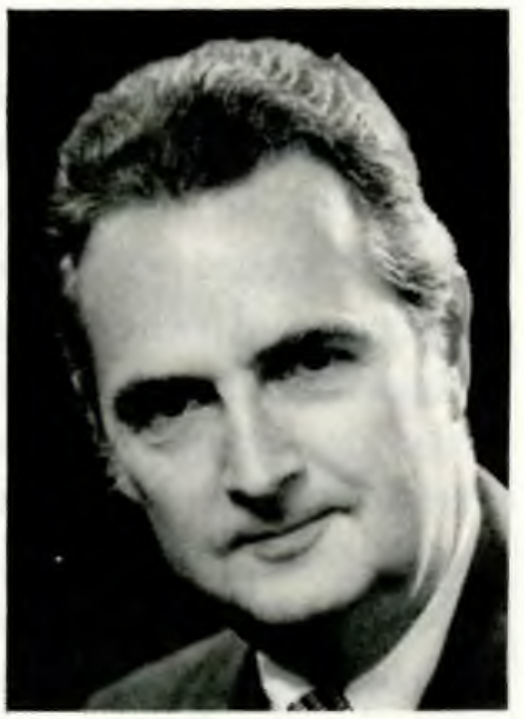

William Budington (1973), as well as his three terms on the Council of the American Li- prior to the election all the nominees for office should be briefed on what the responsibilities of office will be.

Ed.: What made you decide to become a librarian?

Stoffle: I was a Peace Corps volunteer at a secondary school in Barbados. It is a highly educated country but they did not really have school libraries there. I became involved in developing a school library with some students and I discovered that in America I had always taken libraries for granted. When I returned to the United States I took an internship at the University of Kentucky Library to go to library school. My original plan to work in a public library in an outreach program for the disadvantaged did not gel right after graduation, so I got a job in an academic library where I translated many of my concerns about users to the academic environment.

\section{Ed.: Where do you go from here? Will you ever} return to libraries?

Stoffle: I have enjoyed my work as an academic administrator and have learned how universities run and how decisions are made. I would very much like to return to an academic library as a director and put that knowledge to use. I am not sure what may happen in the next few years-I have not closed any options for administration, but my first love is still academic librarianship. I do feel that, whatever else I may be, I am still a librarian.

brary Association (1960-63, 1967-71, and 197982).

Budington was also cited for his achievements as executive director and librarian at the John Crerar Library, Chicago. "Budington has helped bring this unique science library through times of great change and difficulty, helping to move it to the Illinois Institute of Technology campus with additional responsibilities for on-campus service," the citation reads. "During this period Crerar has become an important node in several regional and state networks."

An especially noteworthy accomplishment was the 1981 agreement for a complete merger of John Crerar Library with the University of Chicago. Actual integration of the collections will occur in 1984 when the new John Crerar Library building is scheduled to open on the University of Chicago campus. Budington has been the John Crerar librarian since 1965, and from 1952 to 1965 he served as associate director.

The ACRL Academic/Research Librarian of the Year Award was established by ACRL and the Baker \& Taylor Company to recognize individual 
members of the library profession who have made outstanding national or international contributions to academic or research librarianship and library development. The award consists of $\$ 2,000$ and a citation.

Last year the award was presented to Beverly P. Lynch, librarian at the University of Illinois, Chicago Circle.

\section{DIXON APPOINTED CHOICE EDITOR}

As reported in last month's Late-Breaking News section, the ACRL Board of Directors has approved the selection of Rebecca D. Dixon as the next editor of Choice, ACRL's review journal for college libraries published in Middletown, Connecticut. Dixon is currently the director of the Library Services Division at the Center for the Study of Youth Development, Boys Town, Nebraska, a position she has held since 1975.

Dixon's experience in the application of technology to a wide variety of library operations, her demonstrated management capability coupled with a one-year Council on Library Resources management internship, and her experience in developing a significant library collection and services for a newly-formed research center were the factors that influenced the Choice Editor Search Committee's selection.

Prior to her appointment at Boys Town, Dixon was head librarian at the Institute for Sex Research, Indiana University, Bloomington. She has a master's degree in library science from the University of Indiana (1967) and a bachelor's degree in English literature from the University of Colorado (1961).

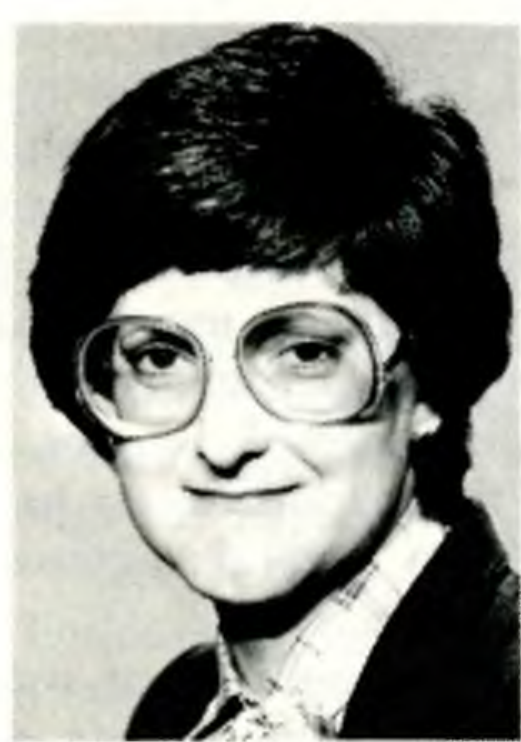

Rebecca D. Dixon

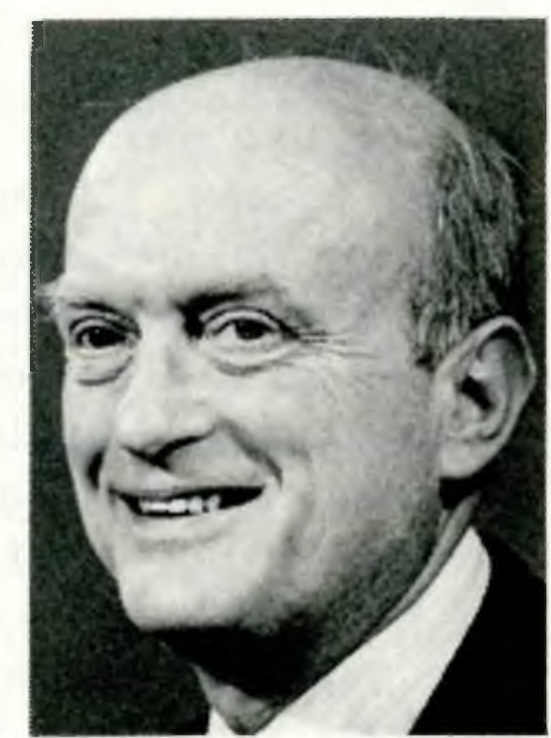

Richard D. Johnson
Dixon replaces Richard D. Johnson, director of libraries at State University College, Oneonta, New York, who has been serving as interim editor of Choice since January. Johnson, who was editor of College \& Research Libraries from 1974 to 1980 and program chair for ACRL's First National Conference in 1978, took a six-month leave from Oneonta during his stay at Choice.
Jay Martin Poole, now assistant director for collection development at Texas $\mathrm{A} \& \mathrm{M}$ University Libraries, was editor of Choice from 1979 to 1981.

Dixon will assume her editorial duties at Choice on August 1, 1982.

Choice is ACRL's current book and nonprint selections guide for undergraduate library collections published eleven times a year. The current annual subcription price is $\$ 60$ until September 1 , after which it will be $\$ 75$. It may be ordered from the Subscription Department, Choice, 100 Riverview Center, Middletown, CT 06457.

\section{CLR REVIEWS INTERN PROGRAM}

Shortly after announcing the names of the five interns selected for the 1981-82 Academic Library Management Intern Program, the Council on Library Resources (CLR) announced that there would not be a 1982-83 class and that the program had been suspended to allow time for a careful review. That review has now been completed and the decision is to continue the program with a few changes for 1983-84.

The management intern program was initiated

\section{CRL Invites Applications for the 1983-84 Internship Program}

The Council on Library Resources invites applications for the 1983-84 Academic Library Management Internship Program. A maximum of five librarians will be chosen to spend nine months working with directors and senior administrative staff at host libraries.

Each intern will be awarded a stipend equal to basic salary and benefits (up to $\$ 25,000$ ) for the nine-month period, and some assistance with moving and other expenses.

Applicants must be citizens of the U.S. or Canada, or have permanent resident status in either country. Experience, education, references, and other factors will be considered in selecting interns. Nearly all interns have had at least five years of professional library experience prior to appointment.

Applications must be postmarked no later than October 11, 1982. For further information and application materials, write: Academic Library Management Internship Program, Council on Library Resources, 1785 Massachusetts Avenue, N.W., Washington, DC 20036. 
in 1973 to provide an opportunity for outstanding mid-career librarians to work closely with directors and administrators of major academic libraries. In eight years there have been 35 interns, selected from 420 applicants. Nearly $\$ 900,000$ has been invested in the program. About two-thirds of the interns have been women, and interns have ranged in age from 29 to 43 . Most have had at least five years of professional experience at the time of selection. Current and former interns hold a number of highly responsible positions, including directorships and assistant/associate directorships in major research and academic libraries.

The review was undertaken to assess the worth of the intern program in the context of costs and need, and to consider all operating aspects of the program in terms of effectiveness and in the context of related opportunities and activities, such as those provided through CLR's Professional Education and Training for Research Librarianship (PETREL) program. Interns, host directors, members of selection committees, and members of the advisory committee for the PETREL program were asked to help assess the value of the program and make suggestions for future changes. Topics addressed during the assessment included the skills and capabilities interns acquire, effects of the internship on the careers of interns, the nature of the mentor/intern relationship, and ways of improving the internship program and the recruiting and selection processes.

The results of the review indicate that the program has been successful in its major objective: to provide an opportunity for librarians with managerial ability and interests to expand their skills and experience. All of the 53 persons responding supported continuation of the program, and most provided both an assessment of the benefits of the internship and suggestions for improvements. The consensus of the group is that this is a unique program that addresses needs not otherwise met.

Because of the positive evaluation, the intern program with a few minor changes will be continued in 1983-84. Up to five interns will be selected. The deadline for applications is October 11,1982 . Persons interested in more information and application materials should write CLR at 1785 Massachusetts Avenue, N.W., Washington, DC 20036.

\section{Bibliographic Instruction}

\section{Extending Library Services to a Field-Based Program}

The Foster G. McGaw Graduate School of the National College of Education, Evanston, Illinois, offers a field-based program for teachers who want to work on their master's degree, but who cannot justify a long drive or time away from their family and workplace. This well-received program has over 40 classes in the Chicago metropolitan area, including groups in Milwaukee, Wisconsin, and Danville, Illinois.

The convenience of having class sessions close to home or place of employment is an important advantage of the program. Teachers find it beneficial to pursue graduate study with colleagues from their own school district. Classes are located in nearby schools, churches, hospitals, and community centers.

The program design includes the integration and application of educational theory and research procedures while a relevant field study is conducted. The field study is defined as a systematic and objective inquiry of a concern, interest, or issue in the teacher's professional field setting. The development and implementation of the field study are continuous throughout the threeterm program.

Because the field-based classes meet off campus, students do not have easy access to the college library. This presents special problems when research must be done for the required individual project. To meet this need, reference librarians from the National College of Education go to field sites to provide the necessary library services and instruction for each group. As a fieldbased group starts its program, a reference librarian meets with the class at a community library close to the meeting site. Before the first class meeting the reference librarian makes contact with the staff of the local community library by phone. Later the librarian makes a personal visit to become familiar with the resources and personnel of that particular library.

At the library session the reference librarian introduces the students to resources in their fields of study. The librarian works in close cooperation with the class instructor to make sure students have hands-on experience with indexes and other 